\title{
Protecting the Mbau Komodo in Riung, Flores: Local Adat, National Conservation and Ecotourism Developments
}

\author{
Halia Asriyani ${ }^{1, *}$ and Bart Verheijen ${ }^{2}$ \\ 1 Peasant School Network of PAYO-PAYO. Maros, South Sulawesi, Indonesia. asriyanihalia@gmail.com \\ 2 Universitas Hasanuddin, Faculty of Forestry, Makassar Indonesia \\ Open Universiteit, the Netherlands \\ * Corresponding author: asriyanihalia@gmail.com
}

\begin{abstract}
The Komodo dragon is one of the most exotic animals of the Wallacea region. Conservation efforts aimed at protecting the Komodo dragon and the unique biodiversity in the region have created a particularly strained relationship between state interests, local livelihood and tourism developments. This article examines recent antagonisms between national agencies, local interests and livelihoods by describing a unique and relatively unknown case study: the Riung Subdistrict and Sambinasi Village and the protection of the Komodo dragons by the local Baar community. Based on information from 19 qualitative in-depth interviews, and the analysis of a recent local Adat meeting in March 2019, this article shows that the Baar were successful in reclaiming land from the national conservation agencies. Meanwhile, they simultaneously formulated new local customary rules on how to treat the Komodo dragon, hence reclaiming ownership over conservation rules and empowering local institutions. Recently, all parties have subscribed to a new ecotourism agenda for further development of the area. This agenda might reshape relations between national agencies and the local communities, as conservation is increasingly linked to new forces of global tourism.
\end{abstract}

Keywords: Komodo dragon; National Parks; Adat; national conservation; ecotourism; Wallacea region

\section{Introduction}

In March 2019 the Baar community, living near the Torong Padang peninsula located at the northwest side of the Riung district in East Nusa Tenggara, Indonesia, sat down in an Adat meeting to discuss local customary rules regarding conservation of land, hunting activities and the protection of terrestrial and marine biodiversity, including the protection of the Komodo dragon. This meeting was the result of a bottom-up initiative taken by representatives from local communities to reclaim conservation regulations regarding the unique biodiversity and the protection of livelihood practices in the area. It was a first reaction to the recent withdrawal of state conservation regulations that had disturbed the local community for over thirty years. During this meeting, where initiatives for new conservation methods and livelihood were discussed, the option of opening up communal customary lands to eco-tourism investments was also addressed.

This article aims to describe and analyze the recent Adat meeting - that can in general terms be defined as a meeting on local customary beliefs, daily practices and social institutions (Erb, 2007) - and its relation to this particular case of community conservation of the Komodo dragons and its surrounding biodiversity in the Riung subdistrict and the village of Sambinasi. The case study adds a new perspective to our understanding of current bottom-up conservation efforts in this relatively understudied region and gives us insights in the strained relations between national conservation methods, livelihood and Adat customs of local communities. Furthermore, it looks at how a reinvention of Adat is used as a tool for constructing new regulations, hereby allowing local communities to reclaim ownership over their communal lands. Adat has been studied extensively from a historical, judicial, religious and social-economic perspective since the end of the 19th century (Davidson and Henley, 2007), however an analysis from a local conservation perspective is 
relatively new (Fasseur, 2007). This perspective understands Adat as a living institution that can be used and reshaped by its subjects in developing and reclaiming conservation methods. The importance of the revivalism of Adat in post-Suharto Indonesia has not yet been fully acknowledged and remains relatively understudied (Henley and Davidson, 2017; Erb, 2007). We therefore assert that this particular case study will contribute to the literature on the revivalism of Adat in its many manifestations, as well provide an in-depth description of local adaptation to new conservation developments in this particular area with its unique wildlife.

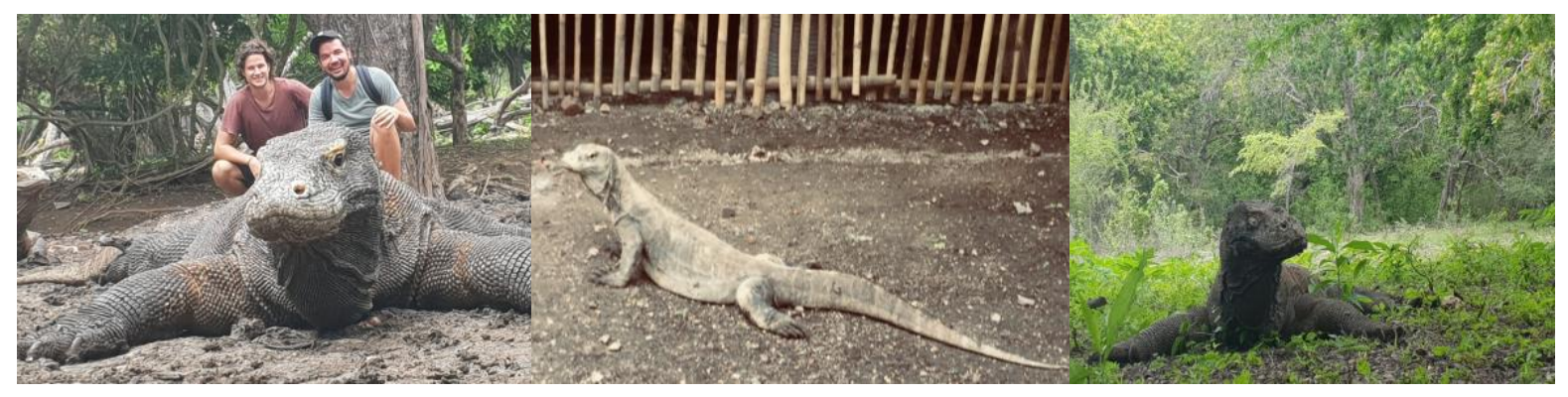

Figure 1. The Komodo dragon in the Komodo National Park

The conservation initiatives described in this case study form a new chapter in developments of state conservation in eastern Indonesia. In Flores, state conservation efforts began to take shape in the 1980s, after the Komodo dragon was given protected status by the Indonesian government. Since then, conservation initiatives in the area have cascaded into the protection and conservation of a vast area around Rinca and Komodo most notably resulting in the establishment of several national parks: the Komodo National Park, Kelimutu National Park and the Riung 17 Islands National Park (see: Flores tourism website). The absolute highlight and symbol of the unique Wallacea biodiversity presented in the Parks is the Komodo dragon, by many considered as one of the most dangerously looking and appealing animals in the world. Komodo dragons are the largest living lizard on earth, and they can be found living on the islands of Komodo, Rinca, Flores, and Gili Motang. For several decades the Indonesian government has developed multiple initiatives to protect the Komodo and the biodiversity of its ecosystem, while at the same time developing the area for tourism (Walpole and Goodwin 2001; Cochrane, 2013; Ariefiandy, 2015; Rodriguez, 2016).

Conservation of biodiversity in Wallacea is rarely a one-sided story. The development of conservation methods has had various (and often far-reaching) effects on the lives of local communities (Tsing, 2005). Conservation efforts often clash with local diversity and interests, including the livelihoods of local communities at conservation sites. Local communities are sometimes considered as an obstacle to the conservation agenda. There is a vast body of literature on the topic, but in general terms the Indonesian conservation agenda was structured using the template of national parks from the United States (Howkins et.al, 2016; Sahide et al., 2018). The construction of national park state conservation was developed during the New Order Regime of Suharto (1966-1998), which saw the benefits in establishing national parks with an international appeal (Rodriguez, 2016). However, these new conservation boundaries would disrupt older, local borders and communities, sometimes resulting in the eviction of communities from national parks areas (Adams and Hutton, 2007; Sahide et al., 2018; Fisher et al., 2019). After the fall of Suharto the pendulum has swung back to regional and local interests and the more recent literature has focused on how to find co-management arrangements between the state and community institutions. New research fields also include the study of the influence of climate change in restructuring conservation in national parks, and the impact of international institutions and international NGOs 
(Demos, 2016). Currently, after forty years of a dominant centralized government Indonesia is still finding a way to establish new working forms of decentralization, while dealing with these new conservation challenges.

This development has also been true for the protection of the Komodo dragon, most notably in the world famous Komodo National Park. Since the implementation of the conservation agenda in the Komodo National Park from the 1980's onwards, multiple conflicts have been reported between locals and conservation agencies (Sitorus, 2011). The conservation initiatives in and around the Komodo National Park have gradually expanded to the protection of other species (both marine and terrestrial), leading to the nomination of the Park as a UNESCO World Heritage site in 1991. The conservation agenda of the park has been co-managed since 1995 by the Nature Conservancy (an American based NGO). Despite several mediation initiatives, conflicts between the local population and the conservation management persisted. The most concerning case was the alleged killing of two local fishermen in 2002 by the patrolling forces of The Nature Conservancy (TNC), when illegally fishing in the park's boundaries (Borchers, 2005). Other reports of the harassing, threatening and even torturing of local fisherman have been reported - although none of these reports is undisputed. In an article published in the in the Jakarta Post in August 2005, researcher Henning Borchers has captured the root of these problems as follows: 'There is a need for transparent and independent review, monitoring and mediation procedures to ensure sustainable management of the park. Local stakeholders have to be involved in decisions pertaining to park management, conservation and economic development (...) They have the right and capacity to make their own decisions about their livelihoods.' (Borchers, 2005).

Research on the relationship between Komodo, tourism, local communities and conservation agenda's is not new. Matthew Walpole has written extensively on the impacts of conservation and tourism and the effects of the conservation agenda in the Komodo National Park. (eg. Walpole et. al 2001; Walpole, 2006; Also; Rodriguez, 2016). Over the last few years, more studies have been conducted to the positive and negative effects on local communities of conservation initiatives. In general it can be said that costs associated with conservation (such as protected wildlife damaging crops) have negative effects on local attitudes towards conservation (Walpole, 2001). On the other hand, once local communities are involved and directly benefit from conservation, they are much more likely to support and embrace conservation goals and participate in conservation management (Sitorus, 2011). Although these general remarks have truth in them, they cannot be applied to different variations in conservation areas without failing to understand internal dynamics between local interests and national sate conservation. For example, Walpole conducted a large survey in Komodo National Park, but did not take the local Adat system into account as the most important forum for communal decision-making.

\section{Method: a local history in interviews}

This article aims to describe and analyze the conservation efforts of the Baar community regarding the Komodo dragons and the surrounding biodiversity, in the Riung subdistrict to the north of Bajawa, in East Nusa Tenggara and the village of Sambinasi. The materials for this analysis were collected by the first author through 19 in-depth qualitative interviews conducted during April 2019 in Sambinasi village. The fieldwork took place at a unique moment in time, namely just after the conclusion of the Adat meeting in which the new conservation rules were determined. The interviews were held with key stakeholders and actors in the process to explore the complexity and context of the recent developments: six community leaders, two traditional religious leaders, eight villagers (three women and five men) and three younger members of the community (one boy and two girls). Other information was collected through the head of Conservation Agency in Riung district, the head of the Tourism Office in Riung and the Komodo Survival Program (KSP) foundation. 


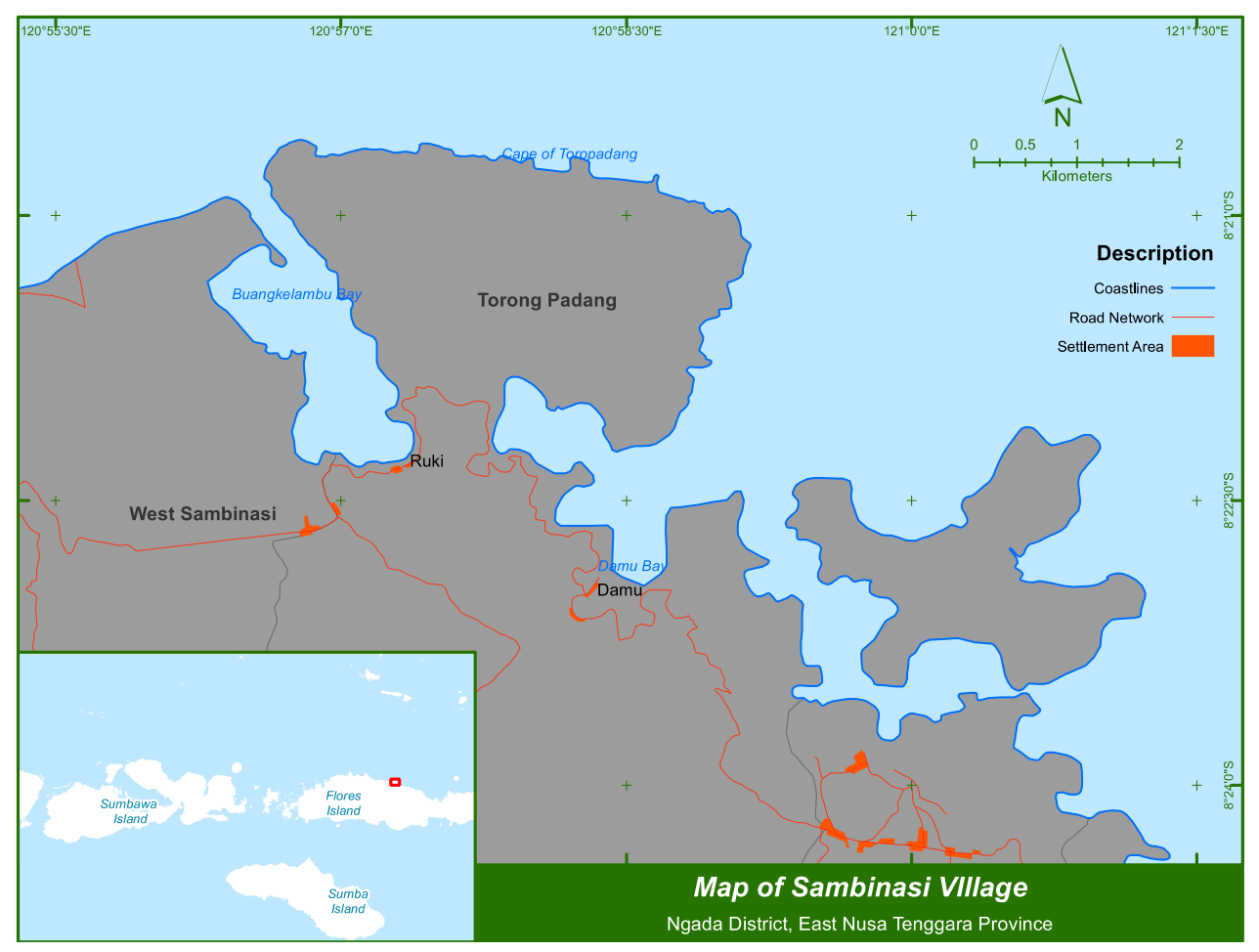

Figure 2. Map of Sambinasi Village in Riung

This article therefore tells the story of the conservation development in Riung through the voices of the local community. Information obtained from the local communities (in particular the key actors) provided a rich source of information to understand the long and unique history of the conflicts surrounding conservation in this area. While we did not conduct a systematic survey among a larger group of village members, we believe that the interviews do give us a representative sample of this particular community and the different viewpoints concerning the conservation efforts. Also, the interviews provided us with the context for this complicated history of the Baar people and their lands. Much of what is known has not been written down and has only survived in communal memory. Topics covered during the fieldwork can be grouped in different categories, and included, but were not limited to: i) the history of the village and the discovery of the Komodo in these areas; ii) the knowledge of the local community of the Komodo, its relation to livestock and personal encounters with the Komodo; and iii) village and community leaders were interviewed about their policies on conservation, their efforts regarding nature protection, tourism development plans and communal known regulations on conservation. In this data collection process community members were actively invited to share the story on how their local community was strengthened in designing rules to safeguard natural resources. By describing and contrasting their answers on the state, Adat and livelihood the antagonism and conflicts surrounding the conservation agenda of the Komodo could be put forward. Most research on conservation of Komodo dragons approach the issue from a top-down level, describing the dynamics between state conservation, global economic tourism developments and NGO' initiatives. These insights are valuable, however they fail to include the local voice of the community in conservation matters. Therefore local reactions to conservation methods are often reduced to 'silent resistance', such as illegal fishing or hunting. During the interviews and as reflected in the Adat meeting, the local community explicitly underlined the possible benefits from future tourist influx in the area. The Adat meeting expressed the desire to explore and develop eco-tourism experiences in and around the village. Therefore this article also wants to say something about the ecotourism initiatives that might be developed in the future. 
What are its expected positive and negative impacts on the conservation agenda, and how will it restructure relations between local community and state conservation interests?

\section{The Baar community in Riung}

The next two paragraphs will provide a short historical introduction and analysis of the relocation of the Baar community and the start of the protection of the Komodo as an endangered species in the community's living area. Both developments heavily influenced the relations between community, livelihood, and Komodo preservation in the Riung area.

The Baar community has a particular and complicated history. All residents who inhabit the Sambinasi village region identify with the Baar tribe community. The Baar tribe itself consists of several small tribes, including the Maki, Buluk, Rungang, Lokon, Medeng, Lindang, Bande Boar, Sari, Pau, Wangkung, Waeraut, Waru, and Walio. ${ }^{1}$ It is this Baar Tribe that resides in the villages around the Torong Padang area: in the West Sambination villages and Sambination Village (see Figure I).

Until forty years ago this area was not inhabited. In 1971, the people of the Baar tribe moved from their homes on the mountain, which they called Taen, to the coastal area Waing Terong. This displacement was initially triggered by the forest location of the residence that made it increasingly difficult for community members to access their land and crops. However, due to a series of local conflicts resulting in the redivision of territory between the Ngada and Manggarai Districts - which sparked a series of violent interventions by the government and the Manggarai community in 1974they moved again and settled in three regions, namely Damu, Ruki and Marotauk (Moeliono and Fisher, 2003). ${ }^{2}$ These three regions later became the three hamlet subdivisions of the Sambinasi village. In 2012, the Marotauk community separated and established its own government, renaming itself the West Sambinasi Village.

The second development was the discovery and classification of the Komodo as a protected species in the Riung area. In 1983, after the establishment of the Komodo National Park and after conducting research in various areas in Flores, the East Nusa Tenggara Natural Resources Conservation Agency (BKSDA) discovered the existence of Komodo species on the Peninsula of Torong Padang. The Peninsula of Torong Padang has an area of 849.6 hectares and is today included in the area of the Sambinasi Village, in the Riung subdistrict. After further research it was established that the Komodo dragons found here were the same type of Komodo as those in the Komodo National Park: Varanus komodoensis. ${ }^{3}$ It therefore obtained the same protective status. There are however physical differences between Komodo dragons found in Riung and those in the Komodo National Park. Most notably: the Komodo dragons from the Riung district are relatively smaller in size. According to the East Nusa Tenggara Natural Resources Conservation Agency this is because Komodos on Komodo Island are fed regularly so that they grow larger in size than the Komodo in Riung, which hunt for their own food. Apart from their body size, there are also differences in skin color. Komodo dragons found on Komodo Island have a darker color, while the Riung Komodo has a brighter color: a greenish yellow (and some even more reddish yellow).

\section{Komodo dragons and communities: Livelihood problems}

Komodo dragons are called 'Mbau' by the Baar people. Since the Baar's resettlement from the mountains to the coastal area near Torong Padang, the Mbau has often been found wandering around their residential areas. Initially the locals were not aware that the 'Mbau' was a type of Komodo. For them, the Mbau is not an important animal and was therefore never considered of

\footnotetext{
${ }^{1}$ Interview with Zakaria, Former Head of Sambinasi Village (April 2019).

2 Interview with Ahmad Dato, Leader of the Sambinasi Village Community (April 2019).

${ }^{3}$ Interview with Niko Manu, Former Head of Riung BKSDA (April 2019).
} 
having an intrinsic value. The Mbau were even considered a 'pest' to the population, because the animal would often prey on their livestock.

To be more exact, tensions between the Komodo and the population emerged after the relocation of the village to the coast. The Sambinasi village community has never held or locked their livestock next to their homes. Livestock in the form of goats, horses and cows are left to search for their own food in the fields located around the settlements near the Torong Peninsula. In the afternoon, livestock will return to the homes of their respective owners. However, it is not uncommon for livestock to return home wounded, or not to return at all. The Komodo is seen as the cause for this damage as most interviewed attributed the missing of livestock to the Komodo. For example, a resident of Ruki Hamlet told us that his two goats had come home with torn wounds. One of them was saved and is still limping, but the other could not be saved. ${ }^{4}$

The local religious hunting ritual creates another problem with the dragon. The Baar tribe has a traditional ceremony connected to the preparation and commencement of the planting season, which they call 'Larik' or 'Caci'. The Larik and Caci ceremonies begin with traditional deer hunting activities. In this hunting ceremony the deers are followed by all Baar people for three days. This traditional hunting activity used to be carried out - after the relocation of the village in the 1970's - in the Baar communal land, the Peninsula of Torong Padang area (Kayat et al. 2017). It is customary to start the hunting ceremony by the burning of the hunting grounds to chase the deer from their hideout. During the hunting ceremony usually a few dozen deer are captured. However, in the last ten years, the number of deer that have been captured has diminished rapidly. According to residents who attended traditional hunting activities since many years, up to 100 deer could be captured between 1980 and 1990. However, only around five to eight deer have been captured during a recent 3-day hunting ceremony.

This hunting ceremony of the Baar tribe is the most exemplary example on how the Baar community and the Komodo dragon are intertwined and brings to light tensions between conservation and livelihood. The hunting ceremony of the Baar tribe is thought to disrupt the population of the Komodo. Komodo dragons feed on deer in this area (and wild boar). A reduced population in deer leads to a reduced food supply for the dragons. This causes Komodo dragons to find other food, like the livestock of the local community. Second, the field fires ignited by the community before the ceremony can lead to a decline of the Komodo population.

For a correct understanding of the relation between the Baar tribe and the Komodo conservation, it should be noted that it was not until very recently that the status of the Komodo was understood by the locals and began to influence their way of living. In 2013, several people from the Bali-based NGO Komodo Survival Program (KSP) began visiting the Riung district. Previously, this organization rolled out a similar program in Komodo Island National Park. The foundation conducted a monitoring program for Komodo species by installing surveillance cameras in locations where the Komodo encounters happened. The camera delivered evidence that the Komodo lived in the Torong Peninsula in Padang. The KSP also began to conduct socialization programs for the community regarding the Komodo, so that slowly the community began to understand that the Mbau in their village was actually a protected type of Komodo. For the past ten years, the Komodo in the Riung district have received additional outside attention. The most important incentive for this is the expected growth in tourism, beyond Java and Bali towards (the national Parks in) Flores. Subsequently, in 2013 an international festival was held. The festival - under the title Sail Komodo was co-organized by the Indonesian Ministry of Maritime Affairs and Fisheries and was attended by representatives from different countries that sailed across the waters of East Nusa Tenggara, including those in the Riung district. The most important goal of the festival was to accelerate economic growth and tourism development in the East Nusa Tenggara region. The Komodo will be presented as one of the selling points of the Riung district (see: Flores tourism website). While plans

\footnotetext{
${ }^{4}$ Interview with Baharuddin, Residents of Sambinasi Village (April 2019).
} 
are still being developed, the arrival of the media, the researchers and tourists' interests for the Mbau have already changed community understanding of the Komodo. In 2017, the KSP began teaching the community about the Komodo and anticipated tourism plans. Some preparation programs for tourism development were carried out in collaboration with the regional government, for example a study tour to Komodo Island National Park, tour guide training, and souvenir-making training. It is expected that these tourism plans further change the way the local community approaches the Komodo ecosystem.

\section{The preservation agenda, local protests and Adat}

Although it feels a bit counter-intuitive, we should not be surprised by the lack of knowledge of the local community towards the Mbau Komodo. Top-down conservation initiatives have shaped and rearranged the protective areas several times over the last thirty years, so we were told during the interviews, but most of these decisions were all taken without the consent of the local Baar community. The Sambinasi village areas have been part of a nature reserve called the Riung Nature Reserve. Initially, the Riung Nature Reserve area was part of the Seventeen Marine Waters Area of 11,900 hectares. In 1996, there was a change in the layout of the Seventeen Sea Water Area of the Island. It was divided into a Seventeen Island Nature Tourism Park of 9,900 hectares and a Riung Nature Reserve of 2,000 ha. Based on the division, the Peninsula of Padang Torong area belonged to the Riung Nature Reserve area. ${ }^{5}$

Through the interviews on the history of conservation in the area we learned that the Baar people themselves never agreed with this top-down implementation of the conservation agenda that established the Torong Peninsula in Padang as part of the Riung Nature Reserve area. The national conservation agenda sparked protest among the community, primarily because the Peninsula of Torong Padang is the location of their traditional ceremonies, as well as a place to herd their livestock. Other areas that were established as part of the Riung Nature Reserve are lands traditionally reserved for farming. The state conservation agenda has been carried out without the knowledge about - and without involving the community in the process of the appointment and establishment of its boundaries. As a result, the community lost confidence in the conservation goals of the government. These people-parks conflicts are not unique for Wallacea. National conservation efforts sparked similar reactions in other parts of Eastern- Indonesia (Tsing, 2005). The national conservation agenda resulted in different forms of protests after 1996. The most common form of public protest was simply ignoring conservation rules, thereby denying their existence. The community continued to carry out hunting activities, both in the form of traditional hunting and poaching and the burning of fields in violation of conservation regulations. The community also continued to plant crops in the Riung Nature Reserve area. These forms of protest persisted because there was no intensive management from the government towards the area designated as a Nature Reserve nor has there been any notable enforcement of conservation rules. The relations between the local community and the Balai Konservasi Sumber Daya Alam (the Nature Conservation Agency Indonesia) reached a new low point in the last decade. The BKSDA would not engage in any talks with the local community, and the local community would not acknowledge the authority of the BKSDA in formulating conservation rules.

This situation changed in 2017. In another administrative stroke of the pen the peninsula of Torong Padang was suddenly excluded from the Riung Nature Reserve by the national Ministry of Forestry, and it was determined that the nature reserve area was reduced from 2,000 hectares to 429 hectares. This newly shaped conservation area no longer includes the Peninsula of Torong Padang. It is unclear to most parties involved why this decision was taken. Again, no consultation with the local communities, or local authorities of any sort took place. The community assumes that

\footnotetext{
${ }^{5}$ Interview with Head of Riung BKSDA (April 2019).
} 
some protests and the bad relationship between them and the BKSDA may have contributed to this decision by the ministry. However the local community was kept in the dark. Similar future topdown decisions on restructuring the nature reserve may occur again, especially since tourism to Flores and its national park's is quickly gaining popularity.

Instead of waiting for these ineluctable new top-down conservation regulations, the community decided to take matters into its own hands. The conservation agenda was recently claimed and embraced by the Baar community. On March 24 2019, a total of fifty residents gathered for an Adat meeting to discuss the management of their customary lands. This meeting was initiated by the residents but facilitated by the Komodo Survival Program (KSP). ${ }^{6}$ Over the last six years, the Sambinasi villagers have been working with the KSP and this Bali-based NGO was happy to assist in the formulation of new conservation rules that would also apply to the protection of the Komodo dragon in the area.

The bottom-up initiative proved to be a very important step in formulating local conservation rules. Until this moment the Mbau had not been included in any customary rules on hunting and farming. After the top- down invention of the Komodo as an endangered species and the rigid forms of state conservation that generated numerous protest by the local community, there now was a window of opportunity to formalize local attitudes and rules towards conservation. The tool used for this was Adat, which is a general terminology for local customary rules and laws that structure daily life (Davidson \& Henley, 2007). And, although the customary rules did not exist in advance, they are embedded in a tradition and system of customary rule not alien to communities in the Wallacea region. For us to understand how this could materialize we need to understand the application of the concept of 'Adat'. Adat is a very complicated concept. In general terms it means a longstanding understanding of unwritten rules that shape local communities and guide behavior concerning a whole range of practices, attitudes towards livelihood and other community initiatives. It has been shaped during the colonial period, and sometimes been reinvented later in post-colonial times, establishing a new relation with religion, state and local regulations. Adat therefore is immensely diverse. It crystallizes at different times in different communities. It takes shape depending on the context, but also can reshape the context it is formulated in. In her work on the diversity of Adat practices in Flores, Maribeth Erb has distinguished three different forms and applications of Adat: Adat as (a display of) culture, Adat as having a ritual or religious ceremonial function and, thirdly, Adat as a political institution, that concerns authority and control over the land. This case study deals with a manifestation of the third type of Adat. Erb argues that this form of Adat emerged after the post-Suharto implementation of the regional autonomy law in 2001 and allows local communities to deal with conflicts over land use (Erb, 2007).

In this particular case study, the local Adat meeting of March 2019 was used to shape unwritten customary laws and practices on conservation and livelihood acknowledging the status of the Komodo and the biodiversity. The community was able to formulate rules both to integrate and regulate the new situation and hereby inventing a new layer of local political authority towards conservation. The best example for this is the alteration of the hunting ceremony. The local community decided to limit their religious hunting practices to once every two years, for two days (instead of the yearly three days event). The Adat meeting kept the initiative within the local community. Therefore this Adat intervention can be regarded as a 1) tool to defend local rights against external interest (state or regional); 2) As a powerful way for developing new regulations for management of resources rooted in local systems of authority. The community was able to formalize other rules as well and the Adat meeting resulted in the following agreements: ${ }^{7}$

\footnotetext{
${ }^{6}$ Interview with Abdul Djalal, Traditional Baar Tribe Leader (April 2019).

${ }^{7}$ Manuscript for the Customary Agreement of the Baar Tribe Community Consultation on March 24, 2019.
} 
1. The Peninsula of Torong Padang is a region that has historical value for the indigenous people of the Baar tribe and has traditional "Pirong" (prohibition) rules that must be respected and carried out by everyone;

2. Customary hunting activities that were carried out every year, are now held every two years with a duration of two days;

3. Everyone is prohibited from hunting deer and other animals in Torong Padang for any reason outside the custom hunting time previously agreed upon;

4. Nobody is allowed to interfere with, nor to capture, injure or hurt Mbau Komodo, which falls under the protection of the Baar Tribe's indigenous people;

5. The Peninsula of Torong Padang area can be used limitedly for ecotourism activities without violating the prevailing customary rules and is fully managed by the Torong Padang management institution consisting of representatives of the Baar tribal indigenous community. Utilization of the Torong Peninsula in Padang must provide the maximum benefit possible to the Baar people;

6. The Peninsula of Torong Padang is managed by fair institutions that represent the indigenous Baar tribe. If needed, the establishment of this institution can be guided by a neutral third party;

7. This agreement will be followed up in the near future to be further strengthened administratively into a Village Regulation that has binding rules.

The customary rules of the 'Pirong' (restrictions and regulations) that were agreed upon at this meeting are further categorized in the Table 1 below:

Table 1. The customary rules of the 'Pirong' (restrictions and regulations)

\begin{tabular}{|c|c|c|}
\hline No & $\begin{array}{l}\text { Customary Law for the Peninsula } \\
\text { of Torong Padang }\end{array}$ & Outcome \\
\hline 1 & $\begin{array}{l}\text { Peninsula of Torong Padang as a } \\
\text { place for hunting, livestock and } \\
\text { livelihood }\end{array}$ & $\begin{array}{l}\text { a. The Peninsula of Torong Padang is a place to hunt; } \\
\text { b. Semananjung Torong Padang as a tourist area for the Baar tribal } \\
\text { community; } \\
\text { c. It is permitted to release livestock in the Torong Peninsula region } \\
\text { of Padang. However, if livestock is eaten by Mbau, the Mbau } \\
\text { should not be killed. }\end{array}$ \\
\hline 2 & Pirong plants & $\begin{array}{l}\text { a. Planting is allowed in gardens that have been used for a long } \\
\text { time (by ancestors), but may not be extended anymore; } \\
\text { d. b. It is not permissible to trade garden land that enters the Tanah } \\
\text { Pirong area (Torong Padang). }\end{array}$ \\
\hline 3 & $\begin{array}{l}\text { Pirong on building a residential } \\
\text { building }\end{array}$ & $\begin{array}{l}\text { a. Nobody is allowed to build residential buildings on the Peninsula } \\
\text { of Torong Padang; } \\
\text { b. The construction of guard posts and surveillance huts is } \\
\text { permissible because they are not included in the settlement } \\
\text { category. }\end{array}$ \\
\hline 4 & Pirong on cutting down of trees & $\begin{array}{l}\text { Nobody is allowed to cut down large trees, mangroves and } \\
\text { sandalwood. }\end{array}$ \\
\hline 5 & Pirong on hunting wild deer & It is not permissible to hunt deer outside customary hunting times \\
\hline 6 & Pirong custom sanctions and fines & 1 bag of rice (around $15 \mathrm{~kg}$ ), 1 goat, and a fine of Rp. 1,000,000 \\
\hline
\end{tabular}


The spirit of the Adat meeting was widely reflected in the interview results. Community members admitted their absolute willingness to protect their natural resources as long as they can also benefit from them. According to one interviewed, the new customary rules are 'actually an attempt to link the rules of law with tradition' (for example, the prohibition on cutting down trees and the prohibition of killing rare animals). Customary rules are also formulated to protect nature as a community, while not disturbing the livelihood of the people. Another important reason that encouraged the Baar people to organize the Adat meeting was the promise of future tourism plans in the area by many different (national and private) stakeholders. The anticipation for this development is stipulated in the fifth article of the agreement. The development of the area for future tourism is not unimportant for the local community and during interviews it was found that the community was keen to embrace future (eco)- tourism developments. Tourism, although the village remains relatively unfamiliar to the idea, is regarded by the community as having a positive effect on the economic situation, even as a replacement for traditional economic activities- under the condition that the community itself is responsible for managing the process. Some locations in the village of Sambinasi are even rumored to have already received offers from investors.

\section{Ecotourism: A new phenomenon for Eastern Indonesia?}

The topic of ecotourism in Indonesia has been studied extensively over the last decades. East Java and the island of Bali are at the center of most studies, however an increasing number of regions of the Indonesian archipelago are touched by a rapid growth in tourism (Hakim et. al, 2009; Byczek, 2011; Wearing et. al, 2009; Scheyvens, 1999; Schellhorn, 2010). Because of its unique biodiversity expectations are that tourism numbers to Flores might quickly go up over the new few years. Flores is currently being promoted as 'authentic' and 'undiscovered' and conservation efforts in the Wallacea region are now increasingly linked with the emerging forces of global ecotourism (Brandon, 1995; Ross, 2001; Borchers, 2002). In general, ecotourism (as a particular form of tourism) dictates that the influx of tourists contributes to the conservation of the protected area and development of local communities by offering alternative forms of livelihood which generate direct and indirect economic benefits, as well as contribute to the management of the area (see also: The international ecotourism society (TIES). Ecotourism might cover the costs for the protection of areas, and can also partly replace traditional forms of livelihood, while at the same time protect and manage traditional hunting and fishing areas (see: Goodwin, 1996; Walpole et al 2001). Another potential positive effect of eco-tourism is the lessening of former antagonisms and enhancing the peaceful cooperation between different actors: local communities and state interests (Sitorus, 2011).

This last section attempts to identity some of the new developments in ecotourism, as well as analyzes some of the possible future challenges for this particular case study. Scholars have described both the benefits and negative effects of ecotourism and most studies agree on the empowerment of local communities as an important positive development. According to Regina Scheyvens, among others, ecotourism can act as an empowering tool when employed on a local level. She asserts that ecotourism can be considered a success 'if local communities have some measure of control and if they share equitably in the benefits emerging from ecotourism activities' (Scheyvens, 1999). The Adat meeting of last March may serve as a first important step towards the empowering of the local Baar community in dealing with future tourism developments. During the meeting, many voices spoke in favor of embracing the tourism industry. In fact it was seen as an important mediation tool by which long-standing resentment and conflict against the national conservation agenda could finally be transformed into a mutually-beneficial experience. The participants during the interviews expressed the idea that ecotourism could increase income and improve economic conditions. Some residents plan to set up restaurants, others to make and sell 
souvenirs. The formulation of the fifth article of the Adat meeting should ensure that the local community holds a big say in the tourism developments in the future.

Much of the community's assumptions about economic development are based on the experiences from the Komodo National Park. These assumptions are not far-fetched. In fact, as argued before it was the KSP who invited the local community to visit Komodo National Park and learn from their best practices and adaptation to tourism. The study by Walpole and Goodwin on local attitudes towards tourism in the Komodo National Park shows that there is much support among the local population for the protection of the Komodo National Park by the state. This conservation was mediated through tourism. Support for tourism, therefore leads to positive attitudes towards conservation. Quantitative studies in other regions dealing with conservation and ecotourism, show similar effects (for an overview: Krüger, 2005). However, the submerging between conservation efforts, local interests and the embracing of the new tourism agenda may create new types of conflict and problems. These developments are yet to take place, but the last part of this article will try to distinguish and discuss the most important ones.

First of all, it is not likely that all locals share the same positive attitude towards tourism. Equal distribution of revenue gained from ecotourism is still a complicated puzzle to solve. According to Walpole's research on Komodo National Park, those benefiting directly from tourism show lower support for conservation agendas. In addition, if tourism is mediated through the state's conservation agenda, the relationship between local support and conservation is not always as clear. The majority of tourists visit the park in pre-booked packages and cruise tours. Most profit has been generated outside the region (Borchers, 2008) and tourism profits in the Komodo National Park are not equally distributed (Walpole and Goodwin, 2001). In fact, most benefits go to the local elites or outsiders. Prices of goods and services are expected to rise, damages or alterations to local culture are likely to occur. Big investors may buy land previously owned by the community. Although tourism has a significant impact on the local economy, local residents are not directly uplifted by the tourism development. This is problematic because the locals are the most dependent on natural resources that the conservation agenda is removing (Walpole \& Goodwin, 2001; Cochrane, 2013). If the area is to be protected, the local community is the most important partner. The ecotourism approach that leaves out the often internally conflicting livelihood situation of the local community, and fails to align it with the tourist and conservation agenda, will never succeed. It may still leave local communities struggling.

Second, the Baar community may benefit from the tourism agenda, as their own culture might be turned into a tourist attraction. This is a difficult dynamic, and cultural studies have since long analyzed the consequences of the touristic gaze and authenticity on local indigenous communities. In addition to environmental impacts that compromise sustainability in Southeast Asia (Dolezal and Trupp, 2015), tourism leads to changing socio-cultural dynamics, including transformations in gender relations, cultural commodification, and the use of heritage for economic and political ends. It can be argued that the touristification of local authentic communities might turn them into a living museum, which has little to do with the cultural dynamics of the community. The Flores tourism website already states when mentioning the highlights of the area for tourists: 'If you plan to see the national park, you should also take some time for visiting Riung Village, as it offers you the possibility of unique cultural encounters. Lively celebrations of the Ngada people's traditional hunting and boxing is just one part of their manifold cultural life' (Flores tourism website). The discussion on tourists' obsession with authenticity is beyond the aim of this paper. However, it should be noted that local 'authentic' customs, might lose their functions because it is only applied in a touristic context. In fact, the dynamics of the local Adat meeting in the establishment of new rules - that what helped the community in this conservation conflict - might paradoxically prove to be less flexible after it gets attached with a new 'invented' tradition based on touristic demands. Under this pressure it might be more difficult to deal with new problems again, as it will create a 
conflict with tourist interests. This may cause a whole new range of conflicts outside but also inside the local community.

Third, the recent news on the developments in the Komodo National Park should also dampen expectations. Recently, the East Nusa Tenggara (NTT) government, in consultation with the national government, has decided to close down the Komodo Island in order to 'revitalise' it. Officially, this revitalization means 'better forest management', 'better food supply for the dragons', as well as to benefit local residents. Furthermore, the island is being prepped again as a 'world class conservation site'. The government asserts that it will benefit local residents, but no specific explanation is given how this will be implemented. Older and newer antagonisms surrounding the Komodo dragon as touristic object already began to surface. Much of the discussion between Indonesian policy makers happens behind closed doors, but in a recent interview with BBC News the region's governor, Viktor Bungtilu Laiskodat said: 'It's called Komodo Island, so it's for the Komodo not for humans. There will be no human rights there, only animal rights.' The governor implied the eviction of the community who has lived in the area for many generations. The future of the Komodo National Park may foreshadow that of the Riung nature reserve in which the park is turned into an exclusive attraction for (wealthy) tourists. It is in this conflict that the concept of ecotourism shows its Janus face: decisions are now motivated on ecological grounds by the decision makers. This ecological argument might exclude the local community again from the tourism agenda. Examples of arguments employed are: the current tourism numbers are too high and the influx is destroying biodiversity. The tourists cause too much plastic waste and the deer population is rapidly declining, thereby deriving the Komodo dragon of food sources. According to the BBC interview, the governor also sees the local community as a direct threat to the Komodo species. He asserts: 'Deer hunting has got much less, and the community now understands (...) but sometimes we have to work with police and the military to stop it.' If the plans would go through the local community would indeed be robbed of their income, since they turned their attention to tourism industry as the only source of income. As a local says: 'We don't have fishing boats anymore, we can't hunt and we have no land' (quotation from BBC news Henschke and Wijaya (n.d).

Antagonism between the local community and Komodo conservation are again at the forefront in this discussion. The governor envisions a future 'Jurassic Park' idea, with real wild Komodo roaming around the park that is completely separated from the human world and only accessible for tourists that are willing to pay substantial entrance fees. This is however a fake idea and presentation of the Komodo, for this will create an artificial reality on the island, ignoring the historical fact that local communities have lived with the Komodo for many decades.

What will happen with the local livelihood of a community that has adapted itself to the tourism industry? To what degree are expectations on increase in income and revenue from tourism realistic for the local community? These questions require close examination of actual development outcomes and experiences. Now that the Komodo National park is closing its doors, these new developments may gain rapid momentum, and increase the tourism influx to Riung faster than anticipated on.

\section{Conclusion}

This article has provided a description and analysis of recent local conservation efforts by the Baar community directed towards the Komodo Mbau dragon and their communal lands in the Riung area in Flores. To analyze the historically unique development of conservation in this region, we have analyzed this case study from the perspective of a recent local Adat meeting, and showed how Adat was used as a tool to react to national state conservation efforts. The interviews with the local Baar community showed how dynamics between Adat, livelihood and state conservation have played out and how top -down and state driven conservation agendas affected this community. This case study has in particular brought to light how the community would take back control through 
the establishment of local Adat conservation rules. This empowerment of the local community in the decision-making on conservation might establish a positive precedent for future discussions on the status of the Komodo in the Riung district.

A big part of the future conservation agenda has been tied to the development of ecotourism projects in the area. Ecotourism can be a useful tool in the struggle of local communities against implementation of a too rigid national conservation agenda in Indonesia. Ecotourism prioritizes aspects of natural resource conservation, aspects of socio-economic empowerment of local communities and aspects of learning and it therefore clicks into the local Adat initiative of the Baar people. Ecotourism can also partly replace traditional forms of livelihood and at the same time protect traditional hunting and fishing areas. Nevertheless, the concept of ecotourism must remain regulated in a regional context to maintain its sustainability. The recent developments in the Komodo National Park might serve as a warning for this. Now the decision on the closing of the Park has been taken without the consent of the local population, and future plans are being quickly developed without including the interest of locals, the tourism industry might backfire to the local community. The Baar community should maintain the initiative through the legitimacy of the Adat regulations. Only then, we expect that the local efforts will be respected when the tourism industry will focus its full attention on the small community in Flores.

\section{Acknowledgments}

The research was supported by the Critical Ecosystem Partnership Fund (CEPF) through Burung Indonesia. However, this paper solely represents the view of the researchers, and not necessarily those of CEPF. We asked the Bali-based NGO Komodo Survival Program to share their experiences and reports. However, since their research is not finalised yet, they have not been able to share their results on the Komodo program in the Riung subdistrict with us. The authors like to thank the two anonymous reviewers for their useful and insightful comments to the first version of this paper.

\section{Conflicts of interest}

The authors declare no conflict of interest.

\section{References}

Adams, W. M., \& Hutton, J. (2007). People, parks and poverty: political ecology and biodiversity conservation. Conservation and society, 5(2), 147-183.

Ariefiandy, A., Purwandana, D., Natali, C., Imansyah, M. J., Surahman, M., Jessop, T.S., \& Ciofi, C. (2015). Conservation of Komodo dragons Varanus komodoensis in the Wae Wuul nature reserve, Flores, Indonesia: a multidisciplinary approach. International Zoo Yearbook, 49(1), 67-80. doi: https://doi.org/10.1111/izy.12072

Borchers, H. (2008). Dragon Tourism Revisited: The Sustainability of Tourism Development in Komodo National Park. In M. Hitchcock (eds.), Tourism in Southeast Asia: Challenges and New Directions. Copenhagen: Nias Press, pp. 270-285.

Borchers, H. (2005). Komodo Park; A future Jurassic tragedy, Jakarta Post, 12 August 2005, see: https://www.slideshare.net/h.borchers/jurassic-tragedy-presentation

Borchers, H. (2002). Ecotourism as a conservation strategy in Komodo National Park, Indonesia. Conference Contesting Development: Pathways to Better Practice, 3rd Biennial Conference of the International Development Studies Network of Aotearoa New Zealand, Massey University, Palmerston North, pp. 3-5.

Brandon, K. (1996). Ecotourism and Conservation: a review of key issues. Environment Department Paper, nr. 33. World Bank, Washington, D.C. 
Byczek, C. (2011). Blessings for All? Community-Based Ecotourism in Bali Between Global, National, and Local Interests - A Case Study. ASEAS: Austrian Journal of South-East Asian Studies, 4(1), 81-106. doi: https://doi.org/10.14764/10.ASEAS-4.1-5

Dolezal, C., \& Trupp, A. (2015). Tourism and Development in Southeast Asia. ASEAS: Austrian Journal of South - East Asian Studies, 8(2), 117-124. doi: https://dx.doi.org/10.14764/10.ASEAS2015.2-1

Cochrane, J. (2013). Exit the Dragon? Collapse of Co-management at Komodo National Park, Indonesia. Tourism Recreation Research, 38(2), 127-143.

Demos, T. J. (2016). Decolonizing Nature: Contemporary Art and the Politics of Ecology. New York: Sternberg press.

Erb, M. (2007). Adat revivalism in western Flores: Culture, religion, and land. In J. Davidson \& D. Henley (eds.), The Revival of Tradition in Indonesian Politics. The Deployment of Adat from Colonialism to Indigenism. London: Routledge, pp. 247- 274.

Fasseur, C. (2007). Colonial dilemma: Van Vollenhoven and the struggle between adat law and Western law in Indonesia. In J. Davidson \& D. Henley (eds.), The Revival of Tradition in Indonesian Politics. The Deployment of Adat from Colonialism to Indigenism. London: Routledge, pp. 50-67.

Fisher, M. R., Dhiaulhaq, A., \& Sahide, M. A. K. (2019). The politics, economies, and ecologies of Indonesia's third generation of social forestry: An introduction to the special section. Forest and Society, 3(1): 152-170. doi :http://dx.doi.org/10.24259/fs.v3i1.6348.

Hakim, L., Kim, J.-E., and Hong, S.-K. (2009). Cultural Landscape and Ecotourism in Bali Island, Indonesia. Journal of Ecology and Environment. The Ecological Society of Korea, 32(1), pp. 18.

Henley. D \& Davidson, J. (2007). Introduction: radical conservatism- the protean politics of Adat. In J. Davidson \& D. Henley (eds.), The Revival of Tradition in Indonesian Politics. The Deployment of Adat from Colonialism to Indigenism. London: Routledge.

Henschke, R., \& Wijaya, C. (n.d), 'The fight for Dragon island', BBC news https://www.bbc.co.uk/news/extra/5bBE5791M9/The_fight_for_Dragon_Island [accessed 31 July 2019].

Howkins, A., Orsi. J., \& Fiege, M. (2016). Introduction. In idem (eds.), National Parks beyond the Nation: Global Perspectives on "America's Best Idea". Norman: University of Oklahoma Press.

Indonesia: The Nature Conservancy's plans in Komodo National Park, Bulletin 80, 11 March 2004; [https://wrm.org.uy/articles-from-the-wrm-bulletin/section1/indonesia-the-nature conservancys-plans-in-komodo-national-park/ [accessed on 10-01-2020]

Kayat, K., Pudyatmoko, S., Imron, M. A., Maksum, M. (2017). Semi-Commercial and Traditional Hunting of Baar Tribe in Riung, Flores, East Nusa Tenggara, J-PAL, Vol. 8(1).

Krüger, O. (2005). The role of ecotourism in conservation: panacea or Pandora's box? Biodiversity and Conservation, 14(3): 579-600. doi: https://doi.org/10.1007/s10531-004-3917-4

Sahide, M. A. K., Fisher, M. R., Maryudi, A., Dhiaulhaq, A., Wulandari, C., Kim, Y. S., \& Giessen, L. (2018). Deadlock opportunism in contesting conservation areas in Indonesia. Land use policy, 77, pp. 412-424. doi: https://doi.org/10.1016/j.landusepol.2018.05.020

Schellhorn, M. (2010). Development for whom? Social justice and the business of ecotourism. Journal of Sustainable Tourism, 18(1): 115-135. doi: https://doi.org/10.1080/09669580903367229

Moeliono, I., \& Fisher, L. (2003). Research as mediation: linking participatory action research to environmental conflict management in East Nusa Tenggara, Indonesia. Natural resource conflict management case studies: an analysis of power, participation and protected areas, pp. 60-79. 
Rodriguez, S. (2016). Dragons or volcanoes? National parks and nature loving in new order Indonesia, c. 1980-1998. In A. Howkins, et. al, National Parks beyond the Nation: Global Perspectives on "America's Best Idea". Norman: University of Oklahoma Press.

Ross, S., \& Wall, G. (2001). Wallace's line, implications for conservation and ecotourism in Indonesia. In D. Harrison (eds.) Tourism and the Less Developed World: Issues and Case Studies. CABI: Wallingford, pp. 223-234.

Scheyvens, R. (1999). Case Study: Ecotourism and the empowerment of local communities. Tourism Management, 20(2), pp. 245-249. doi: https://doi.org/10.1016/S0261-5177(98)00069-7

Sitorus, T. (2011). Linking conservation of biodiversity and community livelihood in Komodo national Park, Indonesia. In G. Baldacchino \& D. Niles (eds.), Island Futures: Conservation and Development Across the Asia-Pacific Region. Springer: Tokyo, pp. 99-105. doi: https://doi.org/10.1007/978-4-431-53989-6_8

Tsing, A. (2005). Friction. An Ethnography of Global Connection. Princeton University Press: Princeton.

Walpole, M. J., Goodwin, H. J., \& Ward, K. G. (2001). Pricing policy for tourism in protected areas: lessons from Komodo National Park, Indonesia. Conservation Biology, 15(1), pp. 218-227. doi: https://doi.org/10.1111/j.1523-1739.2001.99231.x

Walpole, M. J. \& Goodwin H. J. (2001). Local attitudes towards conservation and tourism around Komodo National Park, Indonesia. Environmental conservation, 28(2), pp. 160-166. doi: https://doi.org/10.1017/S0376892901000169

Wearing, S., \& Neil, J. (2009). Ecotourism: Impacts, Potentials and Possibilities (2nd ed.). Routledge

\section{Websites:}

Flores tourism website: http://florestourism.com/districts/riung-17-islands/ [last accessed 10-012020]

The international ecotourism society (TIES): https://ecotourism.org/ [last accessed 14-01-2020]

Komodo Survival Program: http://komododragon.org/post/detail/32 [last accessed: 02-01-2020] 